\title{
A Behaviour of Axially Loaded Steel Concrete Composite Long Columns with Basalt Fiber
}

\author{
Arunya.A, S.Thendral, R. Chitra
}

\begin{abstract}
Composite sections have numerous favorable circumstances over unadulterated steel and solid segments. From the past examinations, it has been demonstrated that the yield strain of the high-quality steel is more prominent than a definitive compressive strain of the solid when exposed to stacking. Consequently, this investigation is centered around the impact of early solid pounding on the conduct of the composite sections.In order to maximize the contribution of the concrete to prevent early crushing of the concrete, the concrete reinforced with basalt fiber was considered. In this project, there are twenty one column specimens were casted to study the mechanical behavior in detail. The impact of basalt fiber on the quality and disappointment conduct of composite sections were wanted to explore. For the structure of composite sections, the standard Eurocode-4 plan strategy has been pursued. To ponder the test execution of the proposed composite sections, the two closures with stuck help condition and hub stacking tests were considered.

Keywords-Basalt fiber, steel-encased composite columns, concrete filled tubular column, load-carrying capacity.
\end{abstract}

\section{INTRODUCTION}

Composite development using steel and cement are utilized in worldwide nearly when the two materials ended up accessible for auxiliary architects. During the previous couple of decades, steel-solid composite auxiliary frameworks have been utilized in numerous tall structures everywhere throughout the world. The utilization of steel-solid composite segments has expanded simultaneously with the expansion in the development of tall structures and long-length structures. Steel-solid composite segment is a pressure part, involving either a solid encased hot-moved steel area or a solid filled cylindrical segment of hot-moved steel and is commonly utilized as a heap bearing part in a composite confined structure. In a composite segment both the steel and cement would oppose the outside stacking by communicating together by security and rubbing. The solid and steel are joined in such a style, that the upsides of both the materials are used viably in composite section. The lighter weight and higher quality of steel grant the utilization of littler and lighter establishments[1],[3],[5].

Revised Manuscript Received on July 22, 2019.

Arunya.A, Assistant Professor, Department of Civil Engineering, Bharath Institute Of Education And Research, Chennai , Tamil Nadu Email: arunyaaaa@gmail.com

S.Thendral, Assistant Professor, Department of Civil Engineering, Bharath Institute Of Education And Research, Chennai , Tamil Nadu Email: thendral.cs@gmail.com

R. Chitra, Assistant Professor, Department of Civil Engineering, Bharath Institute Of Education And Research, Chennai , Tamil Nadu Email: chitraroopauma@gmail.com
This framework joins the inflexibility and formability of strengthened cement with the quality and speed of development related with auxiliary steel to deliver a monetary structure Composite sections have numerous points of interest over unadulterated steel and solid segments[2 ],[ 4],[6]. To boost the upside of the composite sections, the ongoing investigations have concentrated on the steel encased solid composite segments with various creative adjustments. In this paper, a definitive quality and method of disappointment of steel encased solid composite sections affected by basalt fiber would be intended to ponder in detail

\section{EXPERIMENTAL PROGRAM}

The main objectives of the experimental program were (a) to study the behavior of steel encased concrete and tubular composite columns strengthened with Basalt fiber, (b) to study the effect of fiber reinforcement on composite columns on the basis of ultimate load carrying capacity and failure pattern, (c) to carry out the comparative study of the failure pattern and crushing behavior between controlled steelconcrete composite column and strengthened fiber reinforced steel-concrete composite columns and (d)to predict the axial load carrying capacity of steel-concrete composite columns reinforced with fibers[7],[9], ,111]

\section{Materials}

\section{A. Cement, Fine and Coarse Aggregates}

The locally available ordinary Portland cement with a strength grade of 43 and specific gravity of 3.05 conforming to IS:12269 is used in the present study. Natural medium river sand with the grain size less than $4.75 \mathrm{~mm}$ and specific gravity 2.7 is used as a fine aggregate[8],[10],[12]. Granite stone with particle size $12-16 \mathrm{~mm}$ and specific gravity 2.64 is used as a coarse aggregate. Water quality is maintained in accordance to the quality standards of drinking water with $\mathrm{pH}$ of 6.9.

\section{B.Rebar, Structural Steel and Tube}

The $6 \mathrm{~mm}$ and $8 \mathrm{~mm}$ diameter HYSD steel reinforcement bars of grade Fe415 is used. Structural steel of grade Fe250 is used as a I-section in encased composite columns and tubular section in tubular composite columns[13], [15], [17]

\section{C.Basalt Fibers}

Basalt Basalt is a characteristic, hard, thick, dim dark colored to dark volcanic molten shake starting at a profundity of many kilometers underneath the earth and coming about the surface as liquid magma. What's more, it's dim, dim in

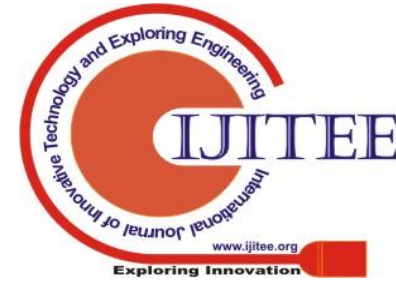


shading, framed from the liquid magma after hardening. The generation of basalt fiber comprises of soften arrangement, expulsion, fiber development, use of greases up lastly winding[14],[16], [18]. This technique is otherwise called turning. A fiber is a material made into a long fiber with a thickness by and large in the request of $300 \mathrm{~g} / \mathrm{cm} 2$ of $50 \mathrm{~cm}$. The perspective proportion of length and measurement can be running from thousand to vastness in persistent filaments. It is don't experience any poisonous response with water and don't dirty air too. The principle elements of the strands are to convey the heap and give solidness, quality, warm dependability and other auxiliary properties in the BFRP. The morphology of the basalt fiber use in this investigation is appeared in Fig. 1. The properties of the basalt fiber utilized in this investigation are recorded in Table 1.

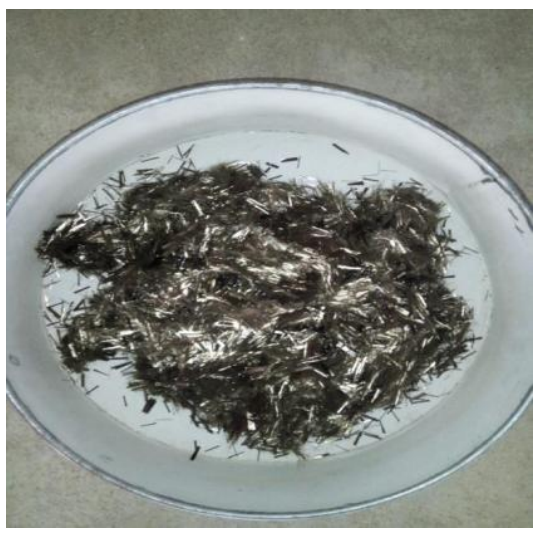

Fig. 1- Morphology of Basalt fiber

Table - 1 Properties of the basalt fiber

\begin{tabular}{|c|l|l|}
\hline \multicolumn{1}{|l|}{ SL. NO. } & CHARACTERISTICS & \multicolumn{1}{c|}{ VALUE } \\
\hline 1. & Density & $2650 \mathrm{~kg} / \mathrm{m}^{3}$ \\
\hline 2. & Tensile strength & $4200 \mathrm{~N} / \mathrm{mm}^{2}$ \\
\hline & & $10500 \mathrm{~kg} / \mathrm{mm}$ \\
& & 2 \\
\hline 4. & Elastic modulus & 0.0315 \\
\hline 5. & Strain at break & $3.1-6 \%$ \\
\hline
\end{tabular}

\section{D.Mix Design}

Blend structure for M25 evaluation concrete by Indian standard prescribed technique for solid blend configuration is followed in this examination (according to IS: 10262-2009). Every solid blend all through the investigation were set up with a consistent water-to-concrete proportion of 0.45 and a focused on compressive quality of $25 \mathrm{MPa}$. The Table 2 speaks to the blend extent of the solid.
Table 2 - Mix proportion of the concrete.

\begin{tabular}{|c|c|c|c|c|}
\hline & Cement & $\begin{array}{c}\text { Fine } \\
\text { Agrre gate } \\
\text { (Sand) }\end{array}$ & $\begin{array}{c}\text { Coarse } \\
\text { Agzregate }\end{array}$ & Water \\
\hline $\begin{array}{l}\text { Weight in } \\
\mathrm{Kg} \\
\text { (for yer } \mathrm{m}^{3} \text { ) }\end{array}$ & 425.78 & 708.88 & 1084.12 & 191.6 \\
\hline Rstio & 1 & 1.67 & 2.55 & 0.45 \\
\hline
\end{tabular}

\section{OPTIMUM BASALT FIBER REINFORCEMENT}

There are 42 number of cube specimens were casted with 14 different ratios of basalt fiber reinforcements by varying 0.2 to $2.6 \%$ in concrete volume fraction to find the optimum percentage of basalt reinforcement [31],[33]. The compressive strength of concrete cube specimens was tested at 28 days in accordance with IS:516-1999. The values of compressive strength test of mixes at 28 days are shown in Fig. 2. From the test results, the optimum value of basalt reinforcement was found as $0.4 \%$ of concrete volume fraction.

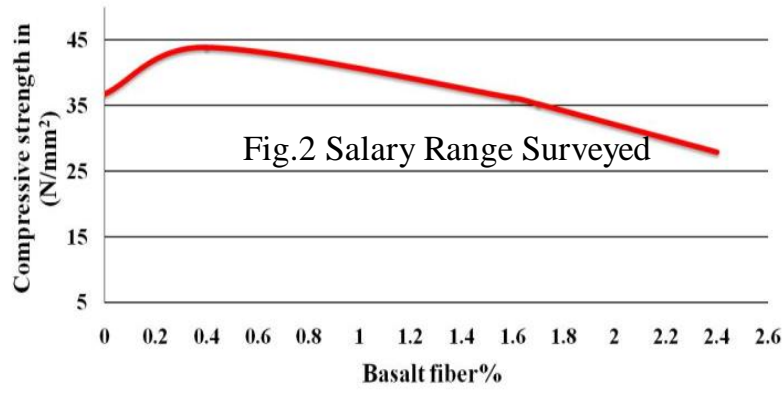

Fig. 2. Comparison of compressive strength

\section{DESCRIPTION OF TEST SPECIMENS}

The test program consists of seven (7) types and twenty one (21) numbers of long columns including controlled specimens. There are three groups of specimens were casted. They areordinary reinforced concrete (RC) column, steel encasedconcrete composite (SECC) columns and concrete filled tubular composite (CFTC) columns with and without basalt fiber reinforcements. The column specimen types and corresponding number of specimens casted were listed in Table 3[32],[34].The concrete filled tubular composite columns were further classified as reinforced concrete filled tubular composite (RCFT) columns and plain concrete filled tubular composite (PCFT) columns[19],[21],[23]. All the specimens were fabricated with same cross section and length as $100 \mathrm{mmx} 100 \mathrm{~mm}$ and $1300 \mathrm{~mm}$. The slenderness ratio of the column is kept constant for all specimens as 45.03. All the columns except the PCFT column type have been reinforced with four $8 \mathrm{~mm}$ 
diameter longitudinal bars at each corner of the section and $6 \mathrm{~mm}$ diameter lateral reinforcements at $20 \mathrm{~mm} \mathrm{c/c}$ spacingthroughout the length. The ratio of structural steel section area to the grossconcrete area of the cross section is 0.0207. The concrete filled tubular composite columns were casted with the marketavailable hot rolled hollow tubular section of size $100 \mathrm{mmx} 100 \mathrm{~mm}$ in cross section and $3 \mathrm{~mm}$ minimum thickness is used[20],[22], [24]

Table - 3 Name of Specimen

\begin{tabular}{|c|c|c|c|}
\hline SI & Name of Specimen & 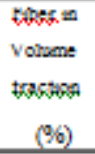 & $\begin{array}{l}\text { Na. } \\
\text { of } \\
\text { Corveme }\end{array}$ \\
\hline 1. & Ordinary reinforced Column (RC) & - & 3 \\
\hline 2. & $\begin{array}{l}\text { Basalt fiper reinforced R.C Column } \\
(\mathrm{Br} \mathrm{KC})\end{array}$ & 0.4 & 3 \\
\hline 3. & 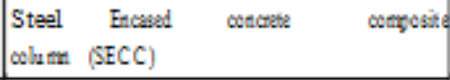 & - & 3 \\
\hline 4. & $\begin{array}{l}\text { Busals fher tinfitced Encased } \\
\text { composite column (BFSECC) }\end{array}$ & 0.4 & 3 \\
\hline 5. & $\begin{array}{l}\text { Reinforced concrete filled tubular } \\
\text { composite columns }(\mathrm{KCF}-\mathrm{I})\end{array}$ & - & 3 \\
\hline 6. & $\begin{array}{l}\text { Plain concrete filled tubular composite } \\
\text { columns (PCFT) }\end{array}$ & - & 3 \\
\hline 7. & $\begin{array}{l}\text { Basalt reinforcad concrete filled tubular } \\
\text { composite columns (BFRCFT) }\end{array}$ & 0.43 & \\
\hline
\end{tabular}

\section{TEST SETUP AND INSTRUMENTATION}

\section{A Test on concrete}

The compressive strength and flexural strength of concrete will be evaluated by testing at 28 days in accordance with IS: 516-1999. The split tensile strength of concrete also determined by testing at 28 days in accordance with IS5816:1999[25],[27],[29]

\section{B.Column Test}

The columns were planned to test in pure compression by an UTM (Universal testing machine). The ultimate compressive load capacity of the machine is $500 \mathrm{KN}$. The columns test set-up is illustrated in [26],[28],[30], which shows the general characteristics of the testing platens and the instrumentation used in the testing. Axial load will be applied to the composite columns specimens at the rate of 5 $\mathrm{KN} / \mathrm{s}$ to find the ultimate load carrying capacity. The reading of axial load and lateral displacement will be measured by using an electronic data acquisition system during testing of each specimen.

\section{CONCLUSION AND FUTURE PLAY}

The experimental study shows that the basalt reinforcement in concrete increases the compressive strength of concrete. It also reveals that the inclusion of basalt fibers into concrete mixture reduces the workability with increasing fiber content.
The column specimens were in the curing process. So, it's unable to present the entire result of this study. After testing the specimens experimentally, the numerical study is also planned to carry out in Finite Element Analysis software ANSYS (Civil FEM). The result from both studies will be compared to find the accuracy of the study. By the analysis of results, we will try to find the empirical relations for predicting the basalt reinforced composite columns load carrying capacities. We expect that the intrusion of basalt fiber in the concrete will improves the load carrying capacity of the column and increases the concrete contribution in composite column by reducing the premature concrete spalling.

\section{REFERENCES}

1. Iyappan L., Dayakar P., Identification of landslide prone zone for coonoortalukusing spatial technology, International Journal of Applied Engineering Research,V-9,I-22,PP-5724-5732,Y-2014.

2. Kumar J., Sathish Kumar K., Dayakar P.,Effect of microsilica on high strength concrete, International Journal of Applied Engineering Research,V-9,I-22,PP-5427-5432,Y-2014.

3. Dayakar P., Vijay Ruthrapathi G., Prakesh J., Management of bio-medical waste, International Journal of Applied Engineering Research,V-9,I-22,PP-5518-5526,Y-2014.

4. Swaminathan N., Dayakar P., Resource optimization in construction project, International Journal of Applied Engineering Research,V-9,I-22,PP-5546-5551,Y-2014.

5. Venkat Raman K., Dayakar P., Raju K.V.B.,An experimental study on effect of cone diameters in penetration test on sandy soil, International Journal of Civil Engineering and Technology,V-8,I-8,PP-1581-1588,Y-2017.

6. Saritha B., Chockalingam M.P.,Photodradation of malachite green DYE using TIO2/activated carbon composite,International Journal of Civil Engineering and Technology,V-8,I-8,PP-156-163,Y-2017

7. Shendge R.B., Chockalingam M.P., Saritha B., Ambica A.,Swat modelling for sediment yield: A case study of Ujjani reservoir in Maharashtra, India,International Journal of Civil Engineering and Technology,V-9,I-1,PP-245-252,Y-2018

8. Chockalingam M.P., Balamurgan V.,Modernisation of an existing urban road-sector in Chennai, a case study report,International Journal of Civil Engineering and Technology,V-8,I-8,PP-1457-1467,Y-2017

9. Saritha B., Chockalingam M.P.,Adsorption study on removal of basic dye by modified coconut shell adsorbent, International Journal of Civi Engineering and Technology,V-8,I-8,PP-1370-1374,Y-2017

10. Saritha B., Chockalingam M.P.,Adsorptive removal of heavy metal chromium from aqueous medium using modified natural adsorbent,International Journal of Civil Engineering and Technology,V-8,I-8,PP-1382-1387,Y-2017

11. Chockalingam M.P., Palanivelraja S.,Retrospective analysis of a theoretical model used for forecasting future air quality near the north Chennai thermal power plant,International Journal of Civil Engineering and Technology,V-8,I-8,PP-1457-1467,Y-2017

12. Saritha B., Chockalingam M.P.,Photodegradation of methylene blue dye in aqueous medium by $\mathrm{Fe}-\mathrm{AC} / \mathrm{TiO} 2$ Composite,Nature Environment and Pollution Technology,V-17,I-4,PP-1259-1265,Y-2018

13. Shendge R.B., Chockalingam M.P., Kaviya B., Ambica A.,Estimates of potential evapotranspiration rates by three methods in upper Bhima Basin, In Maharashtra, India,International Journal of Civil Engineering and Technology,V-9,I-2,PP-475-480,Y-2018

14. Shendge R.B., Chockalingam M.P.,The soil and water assessment tool for Ujjani Reservoir,International Journal of Mechanical Engineering and Technology,V-9,I-2,PP-354-359,Y-2018

15. Shendge R.B., Chockalingam M.P.,A review on soil and water assessment tool,International Journal of Mechanical Engineering and Technology,V-9,I-2,PP-347-353,Y-2018

16. Sachithanandam P., Meikandaan T.P., Srividya T.,Steel framed multi storey residential building analysis and design,International Journal of Applied Engineering Research,V-9,I-22,PP-5527-5529,Y-2014

17. Meikandaan T.P., Ramachandra Murthy A.,Study of damaged RC beams repaired by bonding of CFRP laminates,International Journal of Civil Engineering and 
Technology,V-8,I-2,PP-470-486,Y-2017

18. Meikandaan T.P., Ramachandra Murthy A.,Retrofittng of reinforced concrete beams using GFRP overlays,International Journal of Civil Engineering and Technology,V-8,I-2,PP-423-439,Y-2017

19. Meikandaan T.P., Ramachandra Murthy A.,Flexural behaviour of RC beam wrapped with GFRP sheets,International Journal of Civil Engineering and Technology,V-8,I-2,PP-452-469,Y-2017

20. Meikandaan T.P., Murthy A.R.,Experimental study on strengthening of rc beams using glass Fiber,International Journal of Civil Engineering and Technology,V-9,I-11,PP-959-965,Y-2018

21. Meikandaan T.P., Hemapriya M.,Use of glass FRP sheets as external flexural reinforcement in RCC Beam,International Journal of Civil Engineering and Technology,V-8,I-8,PP-1485-1501,Y-2017

22. Saraswathy R., Saritha B.,Planning of integrated satellite township at Thirumazhisai,International Journal of Applied Engineering Research,V-9,I-22,PP-5558-5560,Y-2014

23. Saritha B., Ilayaraja K., Eqyaabal Z.,Geo textiles and geo synthetics for soil reinforcement,International Journal of Applied Engineering Research,V-9,I-22,PP-5533-5536,Y-2014

24. Ambica A., Saritha B., Changring G., Singh N B., Rajen M., Salman Md.,Analysis of groundwater quality in and around Tambaram taluk, Kancheepuram district,International Journal of Civil Engineering and Technology,V-8,I-8,PP-1362-1369,Y-2017

25. Arunya A., Sarayu K., Ramachandra Murthy A., Iye N.R.,Enhancement of durability properties of bioconcrete incorporated with nano silica,International Journal of Civil Engineering and Technology,V-8,I-8,PP-1388-1394,Y-2017

26. Ilayaraja K., Krishnamurthy R.R., Jayaprakash M., Velmurugan P.M., Muthuraj S.,Characterization of the 26 December 2004 tsunami deposits in Andaman Islands (Bay of Bengal, India),Environmental Earth Sciences,V-66,I-8,PP-2459-2476,Y-2012

27. Ilayaraja K.,Morphometric parameters of micro watershed in Paravanar sub-basin, Cuddalore District,International Journal of Civil Engineering and Technology,V-8,I-8,PP-1444-1449,Y-2017

28. Ilayaraja K., Singh R.K., Rana N., Chauhan R., Sutradhar N.,Site suitability assessment for residential areas in south Chennai region using remote sensing and GIS techniques,International Journal of Civil Engineering and Technology,V-8,I-8,PP-1468-1475,Y-2017

29. Ilayaraja K., Reza W., Kumar V., Paul S., Chowdhary R.,Estimation of land surface temperature of Chennai metropolitan area using Landsat images,International Journal of Civil Engineering and Technology,V-8,I-8,PP-1450-1456,Y-2017

30. Chitra R.,Experimental study on beam using steel fiber and latex,International Journal of Civil Engineering and Technology,V-8,I-8,PP-1395-1403,Y-2017

31. Chitra R.,Analysis of traffic and management at Kovilambakkam intersection,International Journal of Civil Engineering and Technology,V-8,I-8,PP-1433-1443,Y-2017

32. Aswathy M.,Experimental study on light weight foamed concrete,International Journal of Civil Engineering and Technology,V-8,I-8,PP-1404-1412,Y-2017

33. Aswathy M.,Wastewater treatment using constructed wetland with water lettuce (Eichornia Crasipies),International Journal of Civil Engineering and Technology,V-8,I-8,PP-1413-1421,Y-2017

34. Kiruthiga K., Anandh K.S., Gunasekaran K, Assessment of influencing factors on improving effectiveness and productivity of construction engineers, 2015, International Journal of Applied Engineering Research, V - 10,I -17,p -13849-13854.

\section{AUTHOR PROFILE}

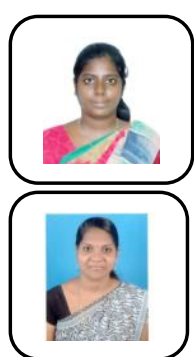

Arunya.A Assistant Professor Department of Civil Engineering, Bharath Institute of Higher Education and Research, Chennai, India

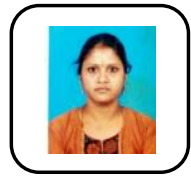

R.Chitra ,Assistant professor, Department of Civil Engineering, Bharath Institute of Higher Education and Research, Chennai, India
S.Thendral Assistant Professor, Department of Civil Engineering, Bharath Institute of Higher Education and Research, Chennai, India

Published By: 